\title{
Profitability of Integrated Farming System model for small and medium farmers of South Tripura, Tripura
}

\author{
D. Sharmah* \\ Krishi Vigyan Kendra- ICAR, South Tripura (Tripura), India \\ B. Debnath \\ Krishi Vigyan Kendra- ICAR, South Tripura (Tripura), India \\ B. K. Kandpal \\ ICAR- Tripura Centre, West Tripura (Tripura), India \\ D. Das \\ Krishi Vigyan Kendra- ICAR, South Tripura (Tripura), India
}

*Corresponding author. E-mail: dasharmah@gmail.com

\begin{abstract}
The present study was carried out under Krishi Vigyan Kendra, South Tripura to study the production, profitability and employment generation of IFS over prevailing conventional rice-rice system of farming in South Tripura district of Tripura during 2015-16, 2016-17 and 2017-18. The components rice, maize, vegetables, ginger, apiculture, fishery, poultry and piggery were considered for the study under integrated farming system. The Integrated Farming System (IFS) model showed $17.79 \%$ increase in productivity and $48.91 \%$ higher net return over conventional rice-rice system. Among the components evaluated, the highest per cent net return was received from Fishery unit (31.78), followed by Piggery unit (18.19), Apiculture (13.93), Poultry unit (12.96), Spice Ginger (10.19), Crop (7.31) and Vegetables (5.64) respectively. The highest B:C ratio (3.67) was obtained from fishery unit among all the component evaluated under the IFS. A total of 289 Man days/ ha/year employments can be generated under Integrated Farming System. This system of IFS model may be useful in the areas where water is limiting and an efficient alternate system of conventional rice-rice system.
\end{abstract}

Keywords: Components, Employment generation, Integrated Farmimg System, Production, Profitability

\section{INTRODUCTION}

The definition of Integrated Farming System (IFS) is varied and dependent on the context. Integrated Farming System (IFS) may be defined in numbers of ways and called as combination of different agriculture system arranged in a variety of probable managerial structured and spatial and sequential manner (Bell and Moore, 2012). IFSs are the agricultural production system with different closely related and interdependent enterprises that interact in space and time to get benefit through a mutualism resource transfer among enterprises (Hendrickson et al., 2008). Integrated farming systems are also considered as a sustainable alternative to profitable farming systems more especially on marginal lands holders with the objective of alternating resource bio-degradation and balancing farm income (Dadabhau and Kisan, 2013). The main emphasis in IFS system is to manage interactions in order to utilize waste from one enterprise becomes an input for another enterprise of the system that reduces the cost of production and environment pollution. The main emphasis of IFSs are the component's inter-dependence within the system, maximum utilization of resources among enterprises and the elasticity in the system make them stable in the long run (Hendrickson et al., 2008). IFSs generally include both crop and livestock enterprises including fishery components called mixed crop-livestock farming or integrated crop-livestock system and can be named them as per combinations of components. In case of crop based IFSs, crop rotation, use of cover crops and to reduce the need for purchase of inputs, use of green manure crops or intercropping helps in retaining nutrients and reduce weed, disease and pest incidences.

The district South Tripura where the present experiment was conducted is mainly dominated by rice-rice mono-cropping system. Out of 41840 hanet sown area only24647 haunder more than once crop per year. Regarding the gross crop area (72685 ha) only 41840 ha area under net crop 
(Bhalerao et al., 2015). The farmers of this region are mostly small and medium land holding in nature, who have already exploited maximum possible per cent of the potential of rice production and further scope for increasing their productivity becomes limited. The climatic condition in the district is also conducive for crop diversification and in some of this area is clear as the income of farmers in decreasing day by day due to their dependency solely on the produce of their traditional mono cropping pattern of rice (Bhalerao et al., 2015). Due to the small land holding of the farmers it become utmost necessary to develop a profitable alternative system that can provide them more income than rice-rice traditional way of cultivation and where only Integrated Farming System (IFS) is the best suited option for increasing the income from their limited land resources. The present experiment was formulated to study the production, profitability and employment generation of IFS over prevailing conventional rice-rice system of farming in South Tripura district.

\section{MATERIALS AND METHODS}

A study was conducted on Integrated Farming System (IFS) at Krishi Vigyan Kendra (ICAR), South Tripura, Tripura during 2015-16 to 201718, involving cropping (Rice, Maize, vegetables), Apiculture, Spice Ginger, Fishery, Poultry and Piggery as the component for integration, and cropping(rice-rice) alone as the control. A Net area of 0.64 ha was considered for integrated farming system, an area of 0.32 ha was allotted for crop component (maize-Maize, vegetables), 10 bee boxes with colony, 0.08ha for spice ginger 0.40 ha for fish pond and 0.04 for Piggery (2:1).Carp poly culture fingerlings @ 10,000/ha (Rohu 20\%, Catla 30\% and Mrigal 40\%) were released into the pond (200 sqm). Fifty poultry birds (BND) were maintained in the poultry shed constructed on the fish pond. This was compared with the conventional rice-rice system.

To serve the feed requirement to fish, poultry droppings were allowed to fall into the fish pond directly and after completing of one year from the time of release of fingerlings, harvesting operation was performed by using drag net. Need based irrigation for crops were provided by lifting nutrient rich water from the fish pond. The details data on production per unit area, economics of each IFS components and the whole integrated farming system were recorded by following standard procedure. The employment generation created from the IFS model was recorded on the basis of man days per ha per year. Since, the study included diversified enterprises like fish, poultry and piggery, the yield was converted into rice equivalent yield as suggested by Singh et. al. (2005).

\section{RESULTS AND DISCUSSION}

The integration of crop with apiculture, spices ginger, fish, poultry and piggery showed higher productivity than the conventional rice-rice cultivation system. Integrated farming system resulted higher productivity (17.79\%) over conventional rice-rice system. Jayanthi et. al., (2003) and Ravishankar et. al., (2007) also reported the similar findings in respect of IFS system. Among the cropping sequences under integrated farming systems, rice-maize yielded the maximum $(1386 \mathrm{~kg} /$ ha/year) closely followed by spice ginger $(1,228 \mathrm{~kg})$, and vegetables (850 kg/ha/year). In case of animal components piggery provided $1,150 \mathrm{~kg} / \mathrm{ha} /$ year higher yield followed by $950 \mathrm{~kg} /$ ha/year in fishery unit and $620 \mathrm{~kg} / \mathrm{ha} /$ year from poultry unit. Sharma and Das (1988) reported that integration of fish-livestock-crop was beneficial. The present study showed that among the cropping sequences, rice-rice system yielded the maximum net returns of Rs. 17,476/-. Cropping (0.56 ha) in IFS led to maximum net returns of Rs.55316 followed by animal components (Rs. 1,50,493/-) (Table 1). The individual unit contributions from cropping, apiculture, poultry, piggery and fishery were 12.95, 13.93, 12.96, 18.19 and 31.78 per cent, respectively. Net returns obtained from all the components was Rs. 1,99,061/- with an increase of 48.91 per cent more over conventional rice-rice system. Behera et al. (2004) also reported increase in returns through IFS. This pre-

Table 1. Production and profitability of different components under IFS

\begin{tabular}{|c|c|c|c|c|c|c|}
\hline Treatment & $\begin{array}{l}\text { Area } \\
(\mathrm{Ha})\end{array}$ & $\begin{array}{l}\text { Productivity } \\
\text { (kg/ha/year) }\end{array}$ & $\begin{array}{l}\text { Gross Income } \\
\text { (Rs.) per ha }\end{array}$ & $\begin{array}{l}\text { Cost of Cultiva- } \\
\text { tion (Rs.) per ha }\end{array}$ & $\begin{array}{l}\text { Net return } \\
\text { (Rs.) per ha }\end{array}$ & $\begin{array}{l}\mathrm{B}: \mathrm{C} \\
\text { ration }\end{array}$ \\
\hline Rice-Maize & 0.32 & 1386 & 36036 & 18560 & 17476 & 1.94 \\
\hline $\begin{array}{l}\text { Vegetables (Tomato } \\
\text {-Bottle gourd) }\end{array}$ & 0.16 & 850 & 25500 & 12020 & 13480 & 2.12 \\
\hline Apiculture & 10 boxes & 370 & 74000 & 40700 & 33300 & 1.82 \\
\hline Spices (Ginger) & 0.08 & 1228 & 36840 & 12480 & 24360 & 2.95 \\
\hline Poultry & -- & 545 & 80600 & 49600 & 31000 & 1.63 \\
\hline Piggery & 0.04 & 1150 & 69000 & 25507 & 43493 & 2.71 \\
\hline Fish & 0.40 & 950 & 104500 & 28500 & 76000 & 3.67 \\
\hline Total & 01 & $6479(17.79)^{*}$ & 438756 & 187367 & 251389 & 2.28 \\
\hline $\begin{array}{l}\text { Conventional Rice- } \\
\text { Rice System }\end{array}$ & 01 & 5564 & 111280 & 58000 & 53280 & 1.92 \\
\hline
\end{tabular}

* Productivity in $\mathrm{kg} / \mathrm{ha} / \mathrm{year}$ andData are the pooled mean of three years 
sent findings was also in conformity with that the irrigated situation rice-fish-vegetables-fruit crops farming system was profitable (Sonjoysha, et. al., 1998).

The benefit cost ratio was also higher (2.28) in the present IFS over conventional rice-rice system (1.92). The financial viability of integrated farming system positively influenced the economic viability of IFSs reported by Radhammani et al. (2003) in his several review studies that confirm the present findings. Among of all components studied, highest benefit cost ratio (3.67) was recorded in fish production followed by spice ginger (2.95) due to low cost of cultivation and was followed by piggery (2.71) (Table 1). Poultry showed the lowest benefit cost ratio (1.63) due to its high maintenance cost. Rice is the labour consuming crop with peak requirement during transplanting, weeding and harvesting. In the present study, IFSs increase the labour engagement of 298 man day/ha/year as compared to 115 man days/ha/year in traditional rice-rice cultivation and is equivalent to $60 \mathrm{per}$ cent of more employment and distributed throughout the year and similar findings was also reported by Sharma et al. (2017). The extra employment generated was due to adoption of intensive cultivation of crops and animal component round the year against the traditional rice-rice cropping system. Due to the diversified nature of activities in respect to different components included in IFS system offer a lot of employment opportunities (289 Man days/ha/year) and helps in fulltime utilization of family labour that leads to employment for rural farmers as well as farm women. Such type of results was also reported by (Mynavathi and Jayanthi, 2015) in their review study on IFS system.

\section{Conclusion}

It can be concluded that Integrated Farming System (IFS) with component like cropping, poultry, fish and piggery was highly productive and profitable and can be advocated for small and medium farmers in South Tripuraas the farmers of the district mostly are small and marginal land holders. This system of IFS model is also applicable in the areas where water is limiting and an efficient alternate system of conventional rice-rice system.

\section{REFERENCES}

1. Behera, U.K., Jha, K.P. and Mahapatra, I.C. (2004). Integrated management of available resources of the small and marginal farmers for generation of income and employment in eastern India. Crop Research. 27:83-89.

2. Bell, Lindsay \& Moore, Andrew. (2012). Integrated crop-livestock systems in Australian agriculture: Trends, drivers and implications. Agricultural Systems, 111. 1-12.

3. Bhalerao, A.K., Kumar, B., Singha, A. K., Jat P.C., Bordoloi, R., Deka, B. C., (2015). South Tripura district inventory of Agriculture. ICAR-Agricultural Technology Application Research Institute, Umiam, Meghalaya, India. PP.19.

4. Chinnuswamy, K. N. (1994). Farming system research and developmentin Cauvery delta and north western zone in Tamil Nadu in:Proc. Int. Fmg Syst. Res. Dev. Sust. Agric., T N, Coimbatore. pp.252-257.

5. Dadabhau, A. S. and Kisan, W.S. (2013). Sustainable Rural Livelihood security through Integrated Farming Systems-A Review. Agri. Reviews, 34: 207-215.

6. Hendrickson, J.R., Hanson, J.D., Tanaka, L.T., and Gretchen, D. S. (2008). Principles of integrated agricultural systems: Introduction to processes and definition. Renewable Agriculture and Food Systems. 23 (4): 265-271.

7. Jayanthi, C., Baluswamy, M., Chinnusamy, C and Mythily, S. (2003).Integrated nutrient supply system of linked components inlowland integrated farming system. Indian Journal of Agronomy. 48: 241-246.

8. Mynavathi, V.S. and Jayanthi C. (2015). Dryland Integrated Farming System-A Review. Agri. Review 36: 67-72.

9. Radhammani, S., Balasubramanian, A., Ramamoorthy, K., and Geethalakshmi, V. 2003. Sustainable integrated farming systems for dry lands: A review. Agricultural Reviews 24:204-210.

10.Ravishankar, N., Pramanik, S. C. Rai, Shakila Nawaz, R. B., TapanK. R., Biswas and Nabisat Bibi (2007). Study on integratedfarming system in hilly upland areas of Bay Islands. Indian Journal of Agronomy. 52: 7-10.

11.Sharma, B. K. and Das, M. K. (1988). Integrated fishlivestock-cropfarming system. Proc. first Indian Fisheries Forum, Mangalore. PP. 27-30.

12.Sharma, R. L., Abraham, S., Bhagat, R. and Prakash O. (2017). Comparative performance of integrated farming system models inGariyaband region under rainfed and irrigated conditions. Indian Journal of Agricultural Research, 51 (1) : 64-68.

13.Singh, J. P., Salaria, A., Singh, K. and Gangwar, B. (2005). Diversification of rice-wheat cropping system throughinclusion of Basmati rice, potato and sunflower in trans-gangeticplains. Journal of Farming System Research and Development. 11: 12-18.

14.Sonjoysha, H., Sinhababu, D. P., Poonan, A. and Jha, K. P. (1998).Integrated farming systems models for integrated and rain fedlowland small farm of coastal Orissa. First International Agronomy Congress,India, pp. 415-416. 